Volume 9. No. 7, July 2021

International Journal of Emerging Trends in Engineering Research

Available Online at http://www.warse.org/IJETER/static/pdf/file/ijeter11972021.pdf

https://doi.org/10.30534/ijeter/2021/11972021

\title{
The Diaphragm Wall Deflection Simulation Project was Tested in Ho Chi Minh City, Vietnam
}

\author{
Huu-Bang $\operatorname{Tran}^{1}$, Hai-Linh Nguyen ${ }^{2}$ \\ ${ }^{1}$ Faculty of Architecture, Thu Dau Mot University, Binh Duong province, Vietnam, \\ bangth@tdmu.edu.vn \\ ${ }^{2}$ Faculty of Architecture, Thu Dau Mot University, Binh Duong province, Vietnam, \\ linhnh@tdmu.edu.vn
}

\begin{abstract}
Checking and calculating the stability of retaining walls and deep excavation are required in the design and construction of subterranean structures, particularly the DW500 reinforced concrete Wall-Plate. This is one of the most significant approaches to preventing landslides and settlement for buildings in the immediate vicinity. In fact, calculating and forecasting the DW500 retainer wall's stability and determining the influent area can provide a variety of options for reducing reinforced frame parts (retaining wall and shoring). This technology is now being explored and used for the most realistic structures in Vietnam, particularly in Ho Chi Minh City. This article uses the finite element technique (FEM - Plaxis 2D-2019) to calculate the lateral displacements, shoring, and outer foundation for the DW500 retaining wall.
\end{abstract}

Key words: Plaxis 2D, Diaphragm Wall-Plate DW500, displacement, and impact surrounding deep excavation.

\section{INTRODUCTION}

Raft foundations - piles are the type of foundation that combines the load carrying capacity of the rafters and pile groups [1], [2], [3], [8]. Some cases of applying pile raft foundation for high-rise buildings in the world [Table 1].

Table 1: Compile a list of projects throughout the world that use pile foundations.

\begin{tabular}{|c|c|c|c|c|}
\hline \multirow{2}{*}{ Projects } & $\begin{array}{c}\text { Height }(\mathrm{m}), \\
\text { Floor }\end{array}$ & \multicolumn{2}{|c|}{$\begin{array}{c}\text { Transmission } \\
(\%)\end{array}$} & \multirow{2}{*}{$\begin{array}{c}\text { Settlement } \\
\text { S }_{\max }(\mathrm{mm})\end{array}$} \\
\cline { 2 - 4 } & Piles & Rafts & \\
\hline $\begin{array}{c}\text { Messeturn, } \\
\text { Frankfurt }\end{array}$ & $\begin{array}{c}257 \mathrm{~m}(843 \mathrm{ft}), \\
\text { 63th }\end{array}$ & 57 & 42 & 144 \\
\hline $\begin{array}{c}\text { Westend 1, } \\
\text { Frankfurt }\end{array}$ & $\begin{array}{c}208 \mathrm{~m}(682 \mathrm{ft}), \\
53 \mathrm{th}\end{array}$ & 49 & 51 & 120 \\
\hline $\begin{array}{c}\text { Skyper, } \\
\text { Frankfurt }\end{array}$ & $\begin{array}{c}154 \mathrm{~m}(505 \mathrm{ft}), \\
\text { 38th }\end{array}$ & 63 & 27 & 55 \\
\hline $\begin{array}{c}\text { QV1, Perth, } \\
\text { West } \\
\text { Australia }\end{array}$ & $\begin{array}{c}163 \mathrm{~m}(535 \mathrm{ft}), \\
40 \mathrm{th}\end{array}$ & 70 & 30 & 40 \\
\hline $\begin{array}{c}\text { Petronas, } \\
\text { Kuala } \\
\text { Lampur }\end{array}$ & $\begin{array}{c}452 \mathrm{~m}(1483 \mathrm{ft}), \\
88 \mathrm{th}\end{array}$ & 85 & 15 & 40 \\
\hline
\end{tabular}

Barrette pile diaphragm walls are erected deep into the earth under the foundation to minimize soil retention and are exposed to horizontal soil movement in high-rise buildings with basements piled raft foundation and basement floor, and diaphragm wall connected with rafters and basement floor to form a system of "Pile Raft Foundation - Diaphragm Wall" (PRF-DW) [Figure 1]. Pressure during the construction of deep excavation pits and system construction of piled raft foundation and basement floor, and diaphragm wall connected with rafters and basement floor to form a system of "Pile raft foundation - Diaphragm wall".

diaphragm wall

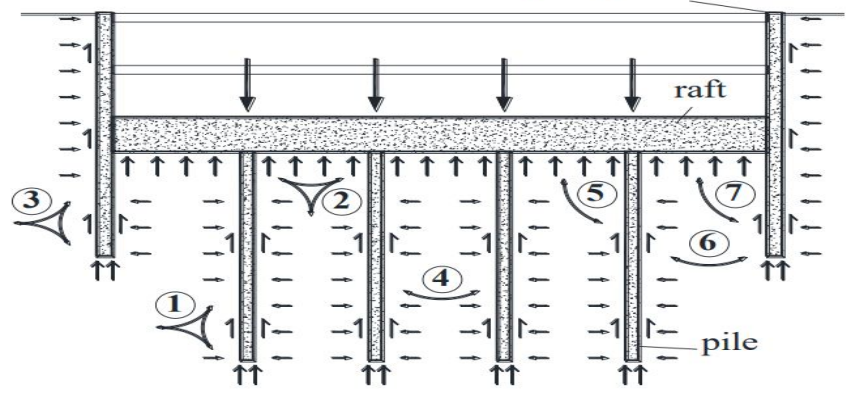

Noted: 1-Interactived pile and soil; 2-Interactived paft and soil; 3-Interactived DW and soil; 4-Interactived pile and pile; 5-Interactived paft and pile; 6-Interactived DW and pile; 7-Interactived $D W$ and paft.

Figure 1: Interactived behavior of the nail system

Only the potential of load-carrying capacity of the rafters and piles was considered in the current research, without addressing the vertical load-carrying ability of the diaphragm wall, in the "Pile raft foundation - diaphragm wall" system, as well as the interaction impact of the diaphragm wall and the pile group in the common working model [4], [5], [6].

During the design and construction of high-rise constructions with inter-floor basements in a smart manner. The diaphragm wall of the deep excavation's horizontal displacement must be monitored. The major causes of landslides are an excavated pit diaphragm wall and adjacent structure settling, which can result in subsidence and collapse of nearby structures. The importance of neighbourhood work in accordance with building stages cannot be overstated.

In the design of deep excavations, a variety of approaches for studying diaphragm wall transverse displacement and settlement of nearby structures are employed, including analytical methods, beam methods on elastic foundations, and finite element methods (FEM). The procedure is more difficult in specific, but it produces 
Huu-Bang Tran et al., International Journal of Emerging Trends in Engineering Research, 9(7), July 2021, 902 - 907

less volatile and reliable analytical findings. (Chang $\mathrm{Yu} \mathrm{Ou,}$ 2006) [7].

Other studies have found that the backdrop model employed has a significant impact on the findings of the stability and horizontal displacement analysis of the excavation pit diaphragm (Vo Phan and Ngo Duc Trung, 2015) [9]. Furthermore, the background models' input parameters have a major impact on the outcomes.

The purpose of this paper is to investigate the horizontal displacement of the basement diaphragm wall and the settlement of the road foundation in Ho Chi Minh City's District 1. Plaxis 2019 - by technique (FEM). The analysis findings provide an acceptable soil model and ground parameters to serve as a foundation for comparison with real DW500 earth retaining wall displacement monitoring, resulting in a reasonable soil model and ground parameters to serve as a basis for design work following stages.

\section{PRIMARY CONTENT}

\subsection{Subjects for research}

Work on the SJC office building was mimicked in the research. The present state of the works is as follows: The left hand side is People's Committee of District 1 (5 floors +2 basements); on the Right there is Villa 26 Phung Khac Khoan (4 floors +2 basements); the front is Sidewalk of Phung Khac Khoan Street and finally inside Existing SJC office (5 floors + 1 basement) [Figure 2 and Figure 3].

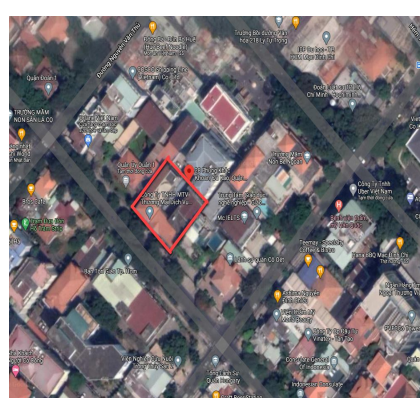

Figure 2. Site of the project

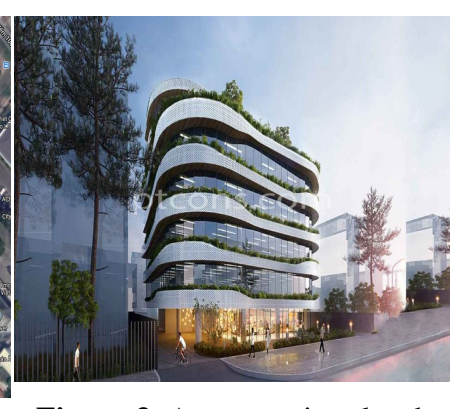

Figure 3. A perspective sketch of the project

\subsection{Data to be entered}

Earth retaining wall DW500 geological structure and parameters Table 2 and Table 3 [10][11].

Table 2: This is the first material in a Plaxis 2D model.

\begin{tabular}{|c|c|c|c|c|c|}
\hline \multicolumn{7}{|c|}{ Material model Hardening Soft Soil } \\
\hline \multicolumn{2}{|c|}{ Parameter } & $\begin{array}{c}\text { Layer of } \\
\text { leveling }\end{array}$ & $\begin{array}{c}\text { Letarit } \\
\text { Sand layer }\end{array}$ & $\begin{array}{c}\text { Clay and } \\
\text { Sand layer }\end{array}$ & $\begin{array}{c}\text { Clay } \\
\text { layer }\end{array}$ \\
\hline $\mathrm{h}$ & $(\mathrm{m})$ & 1 & 7 & 30 & 20 \\
\hline$\gamma_{\text {unsat }}$ & $\left(\mathrm{kN} / \mathrm{m}^{3}\right)$ & 18 & 20.1 & 20.7 & 21.2 \\
\hline$\gamma_{\text {sat }}$ & $\left(\mathrm{kN} / \mathrm{m}^{3}\right)$ & 18.5 & 20.3 & 21 & 21.2 \\
\hline $\mathrm{k}$ & $\left(\mathrm{m} / \mathrm{day}^{3}\right)$ & 2 & 0.00864 & 1 & 0.00864 \\
\hline $\mathrm{E}_{50}$ ref & $\left(\mathrm{kN} / \mathrm{m}^{2}\right)$ & 8000 & 14000 & 16000 & 31500 \\
\hline $\mathrm{E}_{\text {eod }}$ ref & $\left(\mathrm{kN} / \mathrm{m}^{2}\right)$ & 8000 & 14000 & 16000 & 31500 \\
\hline $\mathrm{E}_{\text {rur }}$ ref & $\left(\mathrm{kN} / \mathrm{m}^{2}\right)$ & 24000 & 42000 & 48000 & 94500 \\
\hline $\mathrm{c}^{\prime}$ & $\left(\mathrm{kN} / \mathrm{m}^{2}\right)$ & 5 & 15.3 & 5.5 & 40 \\
\hline$\varphi^{\prime}$ & $\left({ }^{\prime}\right)$ & 20 & 15.72 & 23.7 & 17.2 \\
\hline$\psi$ & $\left({ }^{0}\right)$ & 0 & 0 & 0 & 0 \\
\hline$v$ & - & 0.2 & 0.2 & 0.2 & 0.2 \\
\hline $\mathrm{k}_{0}$ & - & 0.66 & 0.73 & 0.60 & 0.70 \\
\hline $\mathrm{N}_{\mathrm{spt}}$ & - & 0 & 7 & 16 & 37 \\
\hline
\end{tabular}

Table 3: Input parameters for the DW500, Shoring and Kingpost in a Plaxis 2D model.

\begin{tabular}{|c|c|c|c|}
\hline Parameter & Name & Value & Unit \\
\hline Type of behaviour & $\begin{array}{c}\text { Materia } \\
\text { l type }\end{array}$ & Elastic & - \\
\hline Normal stiffness & $E A$ & 13500000 & $(\mathrm{kN} / \mathrm{m})$ \\
\hline Flexural rigidity & $E I$ & 281250 & $(\mathrm{kNm} / \mathrm{m})$ \\
\hline Equivalent thickness & $d$ & 0.5 & $\mathrm{~m}$ \\
\hline Poisson's ratio & $v$ & 0.2 & - \\
\hline $\begin{array}{c}\text { Axial stiffnes-Shoring } \\
\text { H400x400x13x21 }\end{array}$ & $E A$ & $4.10^{6}$ & $\mathrm{kN}$ \\
\hline $\begin{array}{c}\text { Axial stiffnes-Kingpost } \\
\text { H350x350x12x19 }\end{array}$ & $E A$ & $3.10^{6}$ & $\mathrm{kN}$ \\
\hline Spacing-Shoring & $L_{s}$ & 7.0 & $\mathrm{~m}$ \\
\hline
\end{tabular}

\subsection{Techniques of construction calculation}

Simulate the stages of deep excavation construction, as well as the excavation sequence based on recognized building procedures [Figure 4].

Step 1: Build a DW500 diaphragm wall using bored piles and a Kingpost.

Step 2: Start digging for the first time (Cote basement floor 1) Step 3: Set up a shoring system for class 1 vehicles (H400). Step 4: Return to the dirt and dig it a second time (Cote basement floor 2).

Step 5: Install layer 2 of the shoring system (2H400).

Step 6: For the third time, dig the dirt (Cote the bottom of the raft foundation).

Step 7: Basement floor 2 - concrete raft foundation

Step 8: Remove Layer 2 of the Shoring.

Step 9: Layout of the concrete basement level 1.

Step 10: Remove the first layer of shoring.

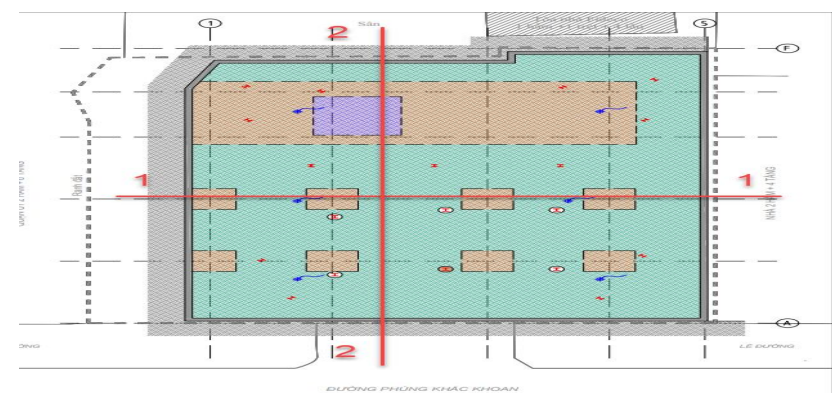

Figure 4. Sections of a Computational Model

2.3.1 Section 1 - 1 Calculation Results: The excavation depth is $9 \mathrm{~m}-9.6 \mathrm{~m}$ and $10.9 \mathrm{~m}$, calculated from the bottom of tunnel B2 to the bottom of the raft foundation. The simulated load is the construction load next to it [Figure 5].

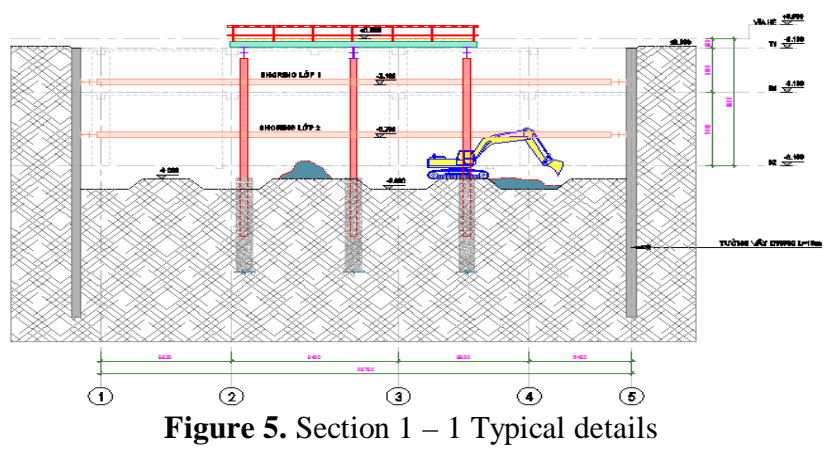


Huu-Bang Tran et al., International Journal of Emerging Trends in Engineering Research, 9(7), July 2021, 902 - 907

* The sequence in which the earthwork construction phases are calculated:

- Phase 1: Status of the Project;

- Phase 2: Consolidation of a building's current load;

- Phase 3: DW500 construction;

- Phase 4: For the first time, dig (basement 1);

- Phase 5: SF1.

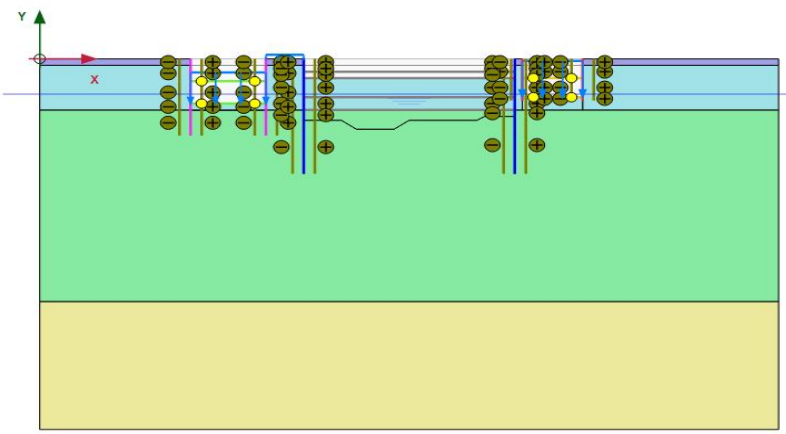

Figure 6. Simulation of a computation for digging a hole

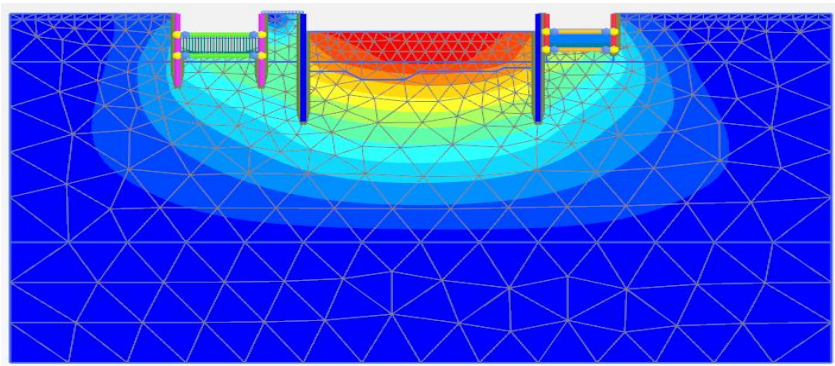

Total displaccments |u| (scaled up 200 times)

Figure 7. Displacement total

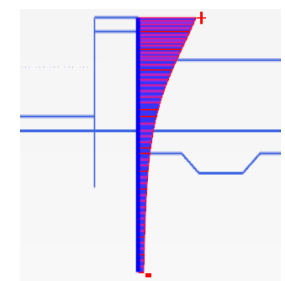

Sum phase displacements $5 \mathrm{SP}_{\mathrm{y}}$ (scaled up 500 times) Maxinum vale $=0.01139 \mathrm{~m}$ (Element 3at Node 5555) Ninimun vale $=1.33^{*} 10^{-3} \mathrm{~m}$ (Eement 82 at Nodet 6179$)$ $U_{x}=1.5(\mathrm{~cm})$

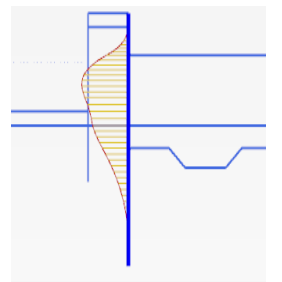

Envelope of Bending moments $M$ (scaled up 0.100 times)

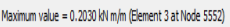
Mnin. $v$ value $=57.70 \mathrm{Wm}$ $M_{\max }=58(\mathrm{kNm} / \mathrm{m})$

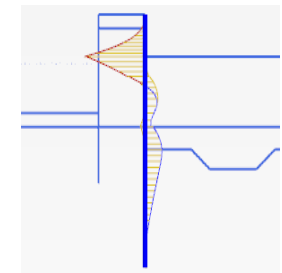

Envelope of Shear forces $Q$ (scaled up 0.200 times)

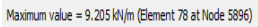
Nirimun value $=-32.69 \mathrm{lN} / \mathrm{m}$ $Q_{\max }=33(\mathrm{kN} / \mathrm{m})$

Figure 8. DW500 (People's Committee of District 1)

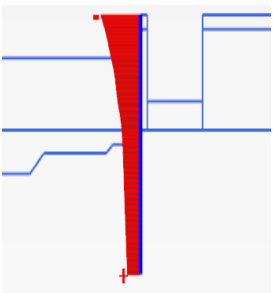

Sun phase displacements SPP $u_{x}$ (scaled up $1.00^{*} 10^{3}$ times)

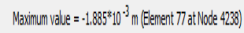

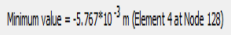

$U_{x}=1(\mathrm{~cm})$

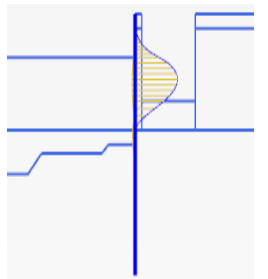

Emvelope of Bending moments $M($ (scaled up 0.200 times)

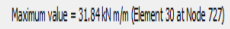
Ninumvaue $=2.294 \mathrm{wmmm}$

$M_{\max }=32(\mathrm{kNm} / \mathrm{m})$

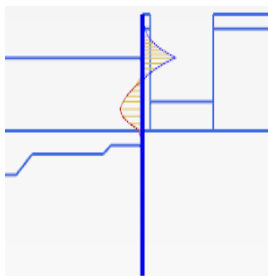

Envelope of Shear forces Q (scaled up 0.200 times)

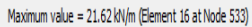
Mrimum value $=-14.24 \mathrm{NN} / \mathrm{m}$

$Q_{\max }=22(\mathrm{kN} / \mathrm{m})$
Figure 9. DW500 (Villa 26 Phung Khac Khoan)

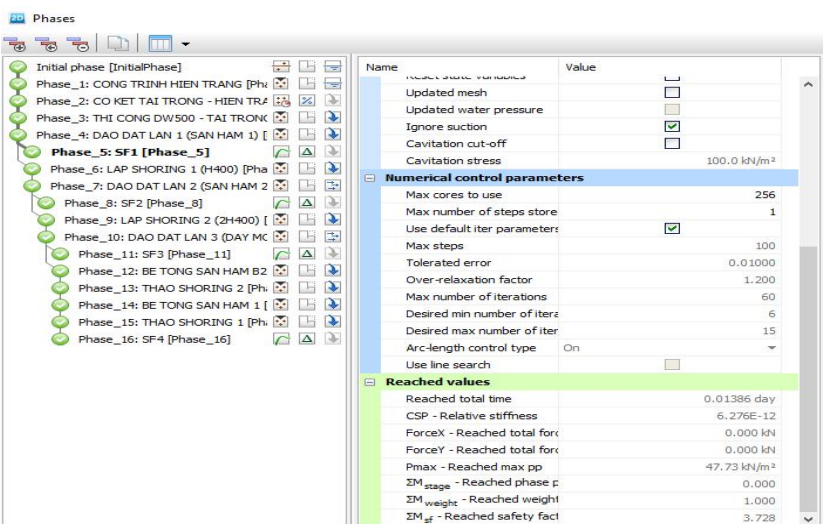

Figure 10. Reached safety fact $M s f=3.728$

- Phase 6: Layer 1 of Mounting Shoring (H400);

- Phase 7: Digging for the second time (Teil floor 2);

- Phase 8: SF2.

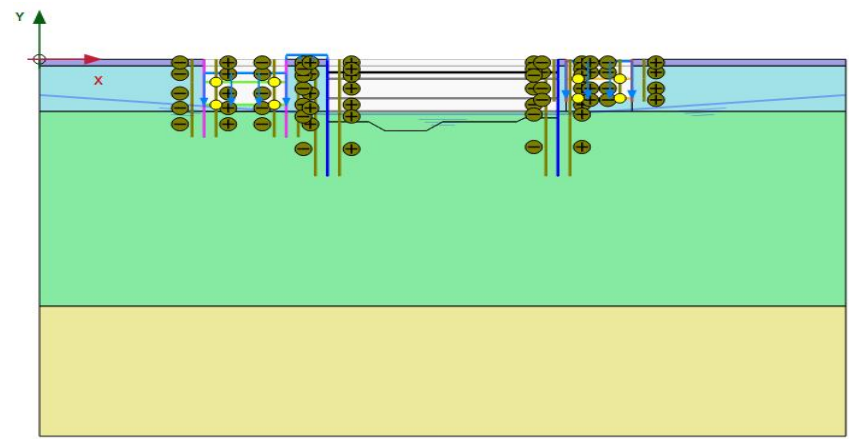

Figure 11. Simulation of a computation for digging a hole

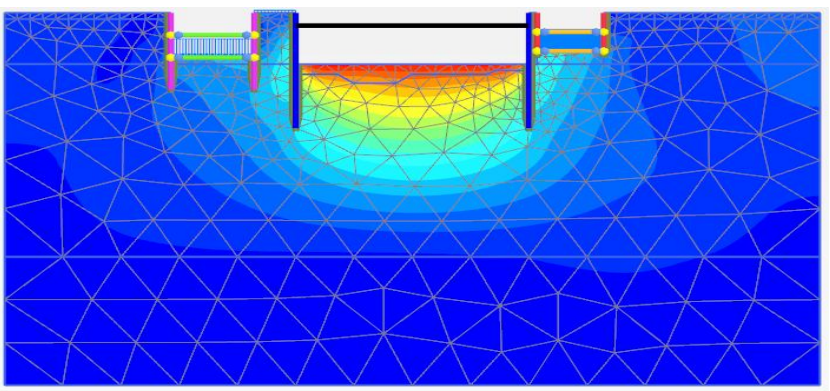

Total displacements $|\mathbf{u}|$ (scaled up 50.0 times)

Figure 12. Displacement total

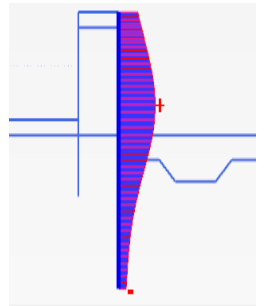

Sun phase displacements SPP $u_{y}$ (scaled up 200 times]

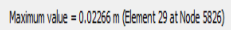

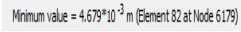

$U_{x}=2.3(\mathrm{~cm})$

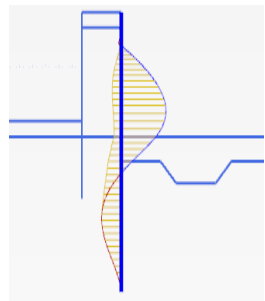

Envelope of Bending monenents $M$ (scaled up 0.0200 times)

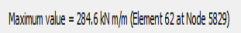

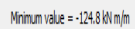

$M_{\max }=285(\mathrm{kNm} / \mathrm{m})$

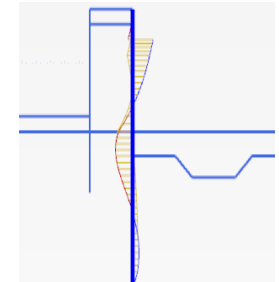

Envelope of Shear forces $Q$ (scaled up 0.0200 tines)

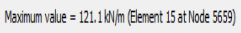
Mininum vale $=-100.0 \mathrm{kN} / \mathrm{m}$

$Q_{\max }=121(\mathrm{kN} / \mathrm{m})$
Figure 13. DW500 (People's Committee of District 1) 


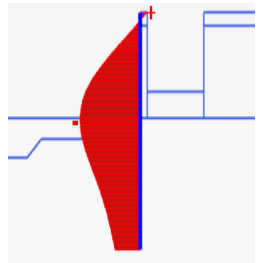

Sum phase displacenents SPP $\mathrm{u}_{\mathrm{y}}$ (scaled up 500 times)

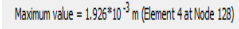

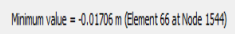

$U_{x}=1.7(\mathrm{~cm})$

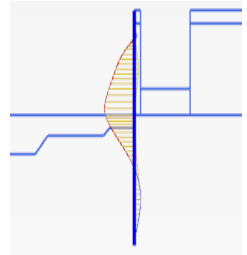

Envelpe of Bending momentis $M$ (scaled up p.0200 times)

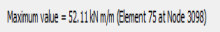

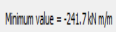

$M_{\max }=242(\mathrm{kNm} / \mathrm{m})$

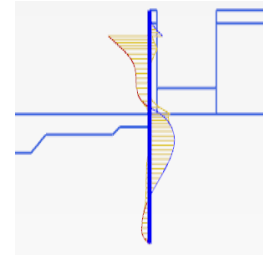

Envelope of Shear forces $Q$ (scaled up 0.0500 times) Maximun value $=67.45 \mathrm{kN}$ (m) (EEment 72 at Node 2138) Mrimun value $=-111.5 \mathrm{~W} / \mathrm{m}$

$Q_{\max }=111.5(\mathrm{kN} / \mathrm{m})$

Figure 14. DW500 (Villa 26 Phung Khac Khoan)

\begin{tabular}{|c|c|c|c|c|c|c|c|}
\hline Structural element & Node ${ }^{4}$ & Local number & $\begin{array}{cc}x & 1 \\
{[m]}\end{array}$ & $\begin{array}{c}\mathrm{Y} \\
{[\mathrm{m}]}\end{array}$ & $\begin{array}{c}\mathrm{N} \\
{[\mathrm{kN}]}\end{array}$ & $\begin{array}{l}\mathrm{N}_{\min } \\
{[\mathrm{kN}]}\end{array}$ & $\begin{array}{l}\mathrm{N}_{\max } \mathrm{A} \\
{[\mathrm{kN}]}\end{array}$ \\
\hline NodeToNodeAnchor_3_1 & 5659 & 1 & 35.000 & -2.000 & -1029.458 & -1029.458 & 0.000 \\
\hline Element 1-1 (Node-to-node anchor) & 333 & 2 & 63.000 & -2.000 & -1029.458 & -1029.458 & 0.000 \\
\hline
\end{tabular}

Figure 15. Shoring strut system response class 1 result

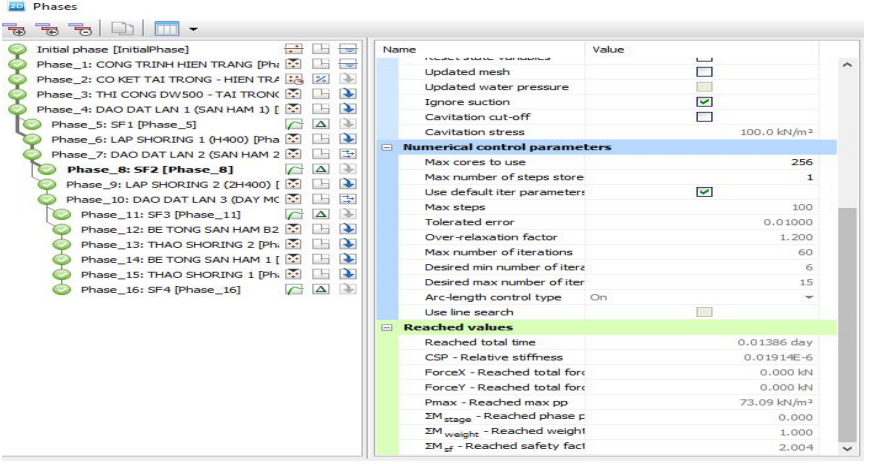

Figure 16. Reached safety fact $M s f=2.004$

- Phase 9: Layer 2 of Mounting Shoring (2H400);

- Phase 10: Digging No. 3 (bottom of raft foundation);

- Phase 11: SF3.

- Phase 12: Filling the basement floor with concrete;

- Phase 13: Remove the second layer of shoring (2H400).

- Phase 14: Basement floor 1 is made of concrete;

- Phase 15: Remove the first layer of shoring (H400);

- Phase 16: SF4.

* Remarks: Internal force and the maximum value of DW500 displacement are added together.

People's Committee of
District 1

\subsubsection{Section 2 - 2 Calculation Results:}

Section 2 - 2: The section estimated from the bottom of the basement floor B2 to the bottom of the raft foundation, with excavation depths of $9-9.6 \mathrm{~m}$ and $10.9 \mathrm{~m}$. Construction live loads and nearby construction loads are examples of simulated loads. The author would like to summarize the findings.
* Remarks: Internal force and the maximum value of DW500 displacement are added together.

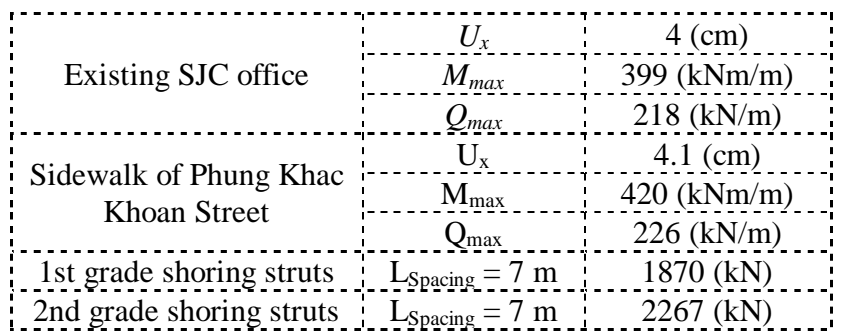

\subsection{Graoundwater flow}

\subsubsection{Section 1 - 1 Calculation Results}

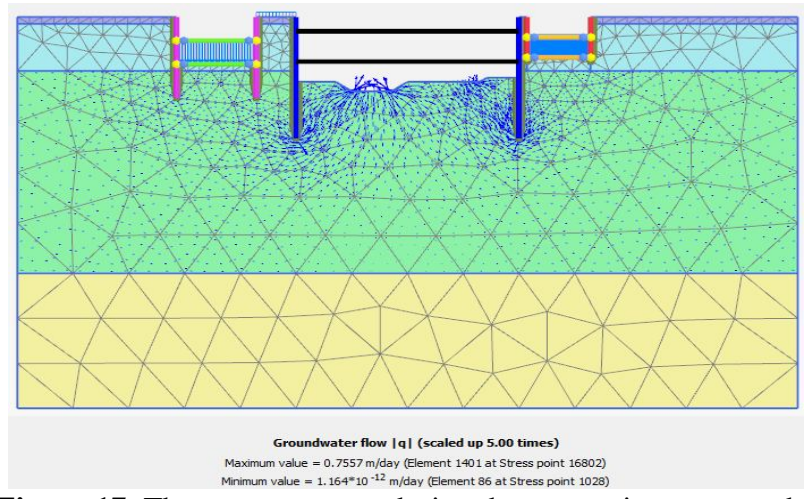

Figure 17. The seepage stress during the excavation stage to the raft foundation's bottom

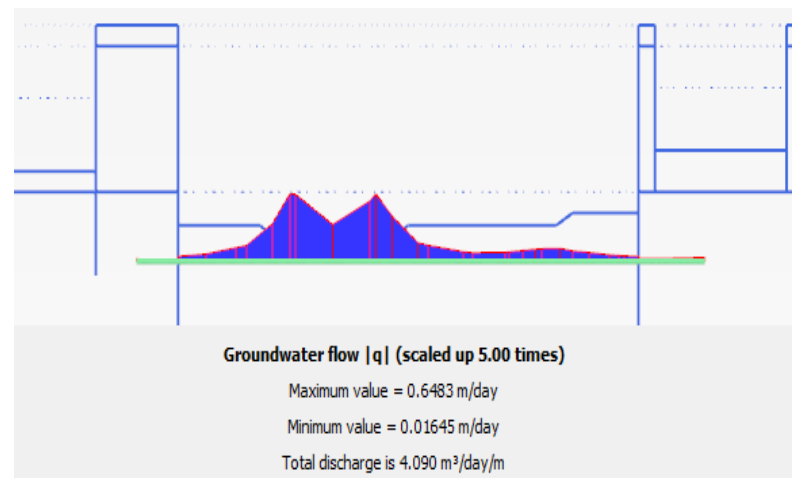

Figure 18. The result of water flowing through the excavation pit's bottom.

\subsubsection{Section 2 - 2 Calculation Results}

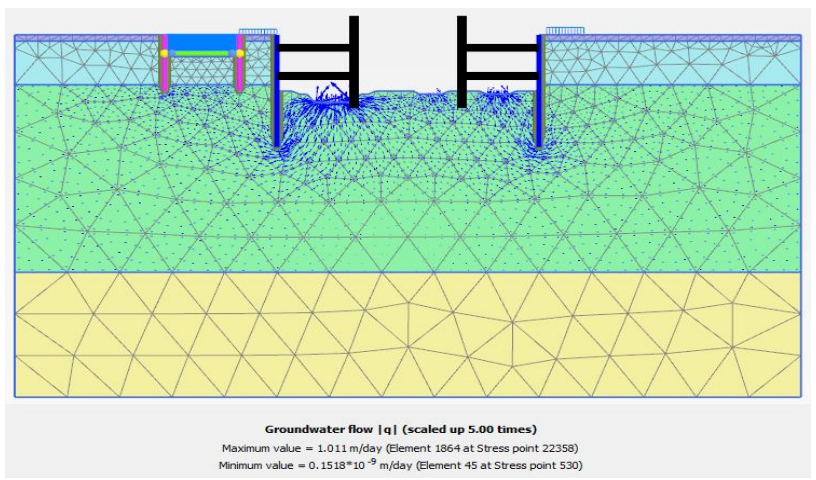

Figure 19. The seepage stress during the excavation stage to the raft foundation's bottom 


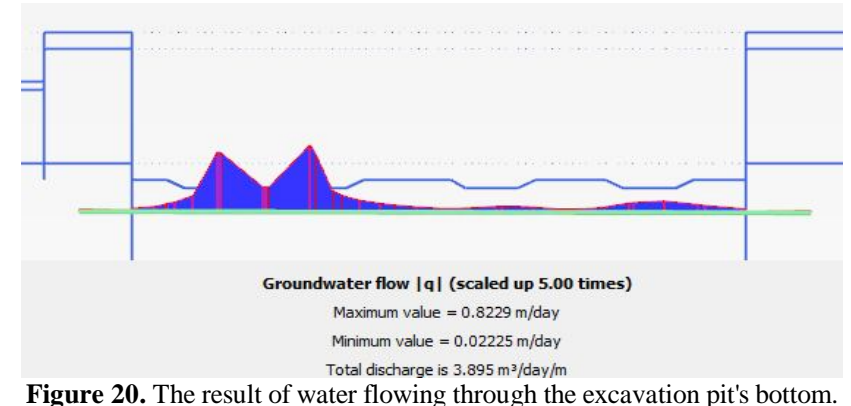

Figure 20. The result of water flowing through the excavation pit's bottom.

* Remarks:

- Total discharge is $\mathrm{Q}=4.1\left(\mathrm{~m}^{3} / \mathrm{day} / \mathrm{m}\right)$.

- The total amount of water that seeps into the structure $\mathrm{Q}_{\text {sum }}=4.1 *(36+28)=262.4\left(\mathrm{~m}^{3} / \mathrm{day} / \mathrm{m}\right)$.

- The number of wells is estimated to be four, with an effective radius of around 15 meters and a capacity of 5-7 horsepower. As a result, 1 pump has the following daily pumping capacity: $\mathrm{Q}_{\mathrm{a}}=262.4 / 4=67\left(\mathrm{~m}^{3} /\right.$ day $)$.

\subsection{Examine the impact of the excavation pit}

\subsubsection{Influence Sphere}

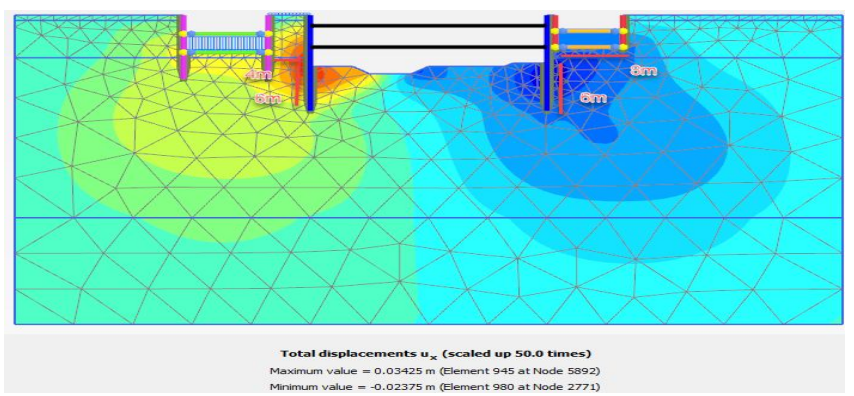

Figure 21. Section 1 - 1 of the Influence Sphere

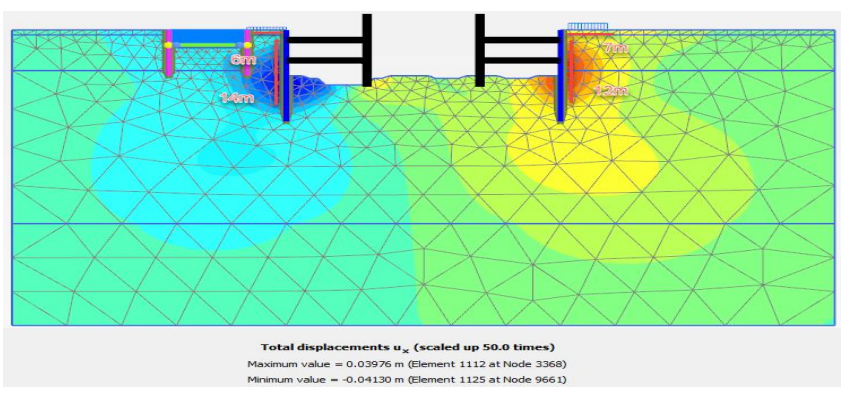

Figure 22. Section 2 - 2 of the Influence Sphere

2.5.2 The following is the foundation for assessing the outcomes of the calculations

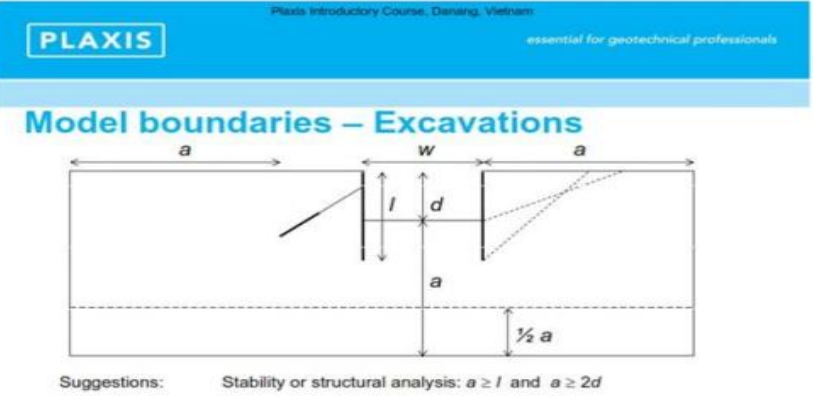

Figure 23. Plaxis 2D Introductory Course

\section{* Remarks:}

- The greatest extent of effect from the position of the excavation border to neighboring structures and existing infrastructure is $8 \mathrm{~m}$, based on the displacement of the surrounding earth during the excavation.

- The deep excavation problem's impact margin is generally more than or equal to 2 times the excavation depth, or greater than or equal to 1 time the excavation's diaphragm wall length. This indicates that the greatest effect range is $\mathrm{R}=2 \times \mathrm{H}=$ $2 \times 9=18 \mathrm{~m}$ or $\mathrm{R}=1 \times \mathrm{L}=1 \times 18=18 \mathrm{~m}$ from the border of the excavation to the surrounding ground.

\section{CONCLUSIONS}

- The bearing capacity is ensured by the DW500 diaphragm wall system, anti-Shoring system, and side beams.

- The diaphragm wall People's Committee of District 1 expects DW500 as the maximum horizontal displacement: 3.4 (cm).

- Villa 26 Phung Khac Khoan is diaphragm wall anticipates a maximum horizontal displacement of DW500: $2.3(\mathrm{~cm})$

- The maximum horizontal displacement estimated for the current SJC office DW500 diaphragm wall: $4.0(\mathrm{~cm})$.

- The diaphragm wall DW500 on Phung Khac Khoan Street's Sidewalk is projected to shift the greatest horizontally: $4.1(\mathrm{~cm})$.

- The number of wells is estimated to be four, with an effective radius of around 15 meters and a capacity of 5-7 horsepower. As a result, 1 pump has the following daily pumping capacity: $Q_{a}=262.4 / 4=67\left(\mathrm{~m}^{3} /\right.$ day $)$.

- The impact margin in basement construction earthworks is restricted to 18 meters.

- Proposed diaphragm wall displacement limit for DW500: $\mathrm{U}_{\mathrm{x} \max }=\mathrm{H}_{\text {digging }} / 150=9 / 150=6(\mathrm{~cm})$.

- The horizontal displacement of the DW500 diaphragm wall system must be monitored during the excavation operation. Simultaneously, frequent monitoring of subsidence and tilting of surrounding works is carried out.

- If a deviation from the warning level is very significant, the appropriate parties must be alerted so that prompt action may be taken.

- The following are some recommended preventative measures: (Stop excavation activity if backfilling is required; Increase the stability of the strut system throughout the excavation process; Maintain command of the situation. To go on to the following phases, you'll need to design and calculate the safety reinforcement. The shoring strut system must be built completely according to the plans).

\section{REFERENCES}

1. Randolph, M.F. Design methods for pile groups and piled rafts. In: Proc. 13th international conference on soil mechanics and foundation engineering, Vol. 5, pp. 61-82, New Delhi, India. 1994.

2. P. Clancy and M.F. Randolph. Simple design tools for piled raft foundations. Géotechnique, Vol. 46 Issue 2, pp. 313-328, June 1996. 
Huu-Bang Tran et al., International Journal of Emerging Trends in Engineering Research, 9(7), July 2021, 902 - 907

3. Poulos H.G. Piled raft foundations: design and applications. Géotechnique, Vol. 51, Issue 2, pp. 95-113, March 2001.

4. Katzenbach, R., et al. High-Rise Buildings In Germany. Soil-Structure Interaction of Deep Foundation. In: Proc. 5th. Int. Conf. on Case Histories in Geotechnical Engineering, New York, NY, Apri 2004, pp.13-17.

5. Sales MM, Small JC, Poulos HG and Harry G. Poulos. Compensated piled rafts in Clayey soils: Behaviour, measurements, and predictions. Can Geotech. J. Vol. 47, 2010, pp. 327-345.

6. Kumar A., Choudhury D. and Katzenbach R.,: Effect of Earthquake on Combined Pile-Raft Foundation. International Journal of Geomechanics ASCE, ISSN 1532-3641; 2016. pp. 1-16.

7. Chang-Yu Ou. (2006), Deep Excavation - Theory and Practice, Taylor \& Francis Group, London, UK.

8. Nguyen Nhut Nhat, Le Ba Vinh and To Le Huong. Analysis of interaction effects of the diaphragm wall and the pile group in Piled raft foundations - Diaphragm wall, Viet Nam Geotechnical Journal. Vol 4, 2020, pp.51-60.

9. Ngo Duc Trung (2015) To stabilize a deep excavation, a displacement study of a retaining wall was performed. (Viet Nam National University Ho Chi Minh City).

10. Plaxis 2D V8.5 (2019). Tutorial Manual.

11. Van-Vinh Nguyen, Thi-Kieu Pham and Huu-Bang Tran. Evaluation of Response Modification Factor of Multiple Story Steel Buildings. International Journal of Emerging Trends in Engineering Research. ISSN 2347-3983, Vol. 8. No. 4, April 2020, pp. 1342-1348. 